\title{
Company town socio-economic transformation: concentration and factors system
}

\author{
Irine S. Antonova ${ }^{1, a}$, Eugeny A. Pchelintsev ${ }^{2}$, Danil D. Vavilov ${ }^{1}$ \\ ${ }^{1}$ National Research Tomsk Polytechnic University, Department of Management, 634050 Tomsk, Russia \\ ${ }^{2}$ National Research Tomsk State University, Department of Mathematical Analysis, 634050 Tomsk, Russia
}

\begin{abstract}
In the article the authors suggest evaluating the level of diversification using HerfindahlHirschman index that reflects the economic activity concentration within the certain timespan. The study of the index in dynamics for Berezovsky company town located in Kemerovo region shows the downward tendency in economic activity concentration whereas its factors remain ambiguous. The research concludes that, on the one hand, a low level of investments in diversification projects does not act upon the diversification process, on the other hand, socio-economic targets of diversification does not correlate with economic structural changes. Thus the diversification process has low effectiveness.
\end{abstract}

\section{Introduction}

The diversification process represents the structural changes in the economy that differs in companies and towns. The only exception is a company town founded on the basis of the core industry or a town-forming enterprise. Green uses the term "single-company community" to underline the deep dependence between the social wellbeing of a town and its town-forming enterprise [1]. The dependence is reflected in a dominant share of a company or industry in dispatched goods, the employment rate, tax liabilities, and investments. The town-forming enterprise or the core industry is basically focused on the outside market being located far from the major labor markets of the country.

The high level of the industry concentration directly influences the company town sustainable development being the main factor of the risk. The diversification process becomes the basic strategy to reduce the dependence and develop sustainability of the company town socio-economic wellbeing. Zemlyansky and Lamanov consider the industrial diversification as a main development strategy for company towns with upward dynamics in socio-economic wellbeing [2]. This strategy is focused on the structural transformation in the company town economy that leads to the cutting down the share of the core industry in dispatched goods, investments, personnel, and tax liabilities and the growth of the non-core industries and small business. Thus, the effectiveness evaluation depends on diversification of progress estimation. In this article we suggest evaluation of the core industry diversification process in dynamics and define the basic factors of economy structural

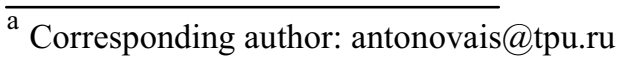

transformations of Berezovsky company town located in Kemerovo region. This region is almost entirely consists of company towns with the only exception of regional center (Kemerovo).

\section{Company towns and Diversification}

Green defines two basic models that modern company towns tend towards: "exploitation ville" and socially benignity [1]. The first type of towns tends to focus on profits and expenses on employees' wellbeing whereas the second one represents an ideal model of a company town. The socially benign town develops schools, hospitals, parks, and desirable housing for its workers as a "model town" of Pullman [3] famous for the paternalistic way of management and development as well as scandals and trials. The offered types can be considered as the poles of the company towns nature (Figure 1). The town-forming enterprise tends to be socially oriented but meets additional expenses on it. Thus, a company town is placed between these two poles and its proximity to the pole reflects the rate of its social responsibility.

Exploitation ville Socially benign

Fig. 1. The poles of social responsibility of socio-economic company towns. 
In this case we insist on the differentiation between social and economic diversification that could be evaluated separately.

\subsection{Economic results of diversification its effectiveness}

\subsubsection{Industry concentration}

The share of a core industry could be estimated in dispatched goods, investments, an employment rate, and tax liabilities. Its changing will cause the transformation of the economy structure that should be studied in dynamics. The statistical measure of concentration is Herfindahl-Hirschman index (HHI) that can be used in the variety of contexts [4-8]. Essentially HHI represents the market structure as shown in the researches conducted by Miller estimated the market shares of individual firms [4]. Nauberg, Basu, and Chand utilized HHI for market segment concentration with an unattributed market share [5]. But the development of M\&A legislation made this index more widespread both in practice and studies [6]. Rhoades considers HHI as efficient screening device both for regulators and banks to plan and control the M\&A operations [7] taking into account the output of banks or other firms. Susilo and Axhausen examine the degree of repetition of individuals' choices of daily activity-travel-location by HHI [8]. Zhemchuzhnicova uses HHI for investments concentration in towns of Orenburg region in Russia [9]. Carson, Carson, and Henderson apply HHI for employment concentration that helps them to conclude relevance between labor growth and newly resident and nonindigenous workers concentration [10]. Taking into consideration these researches HHI could be used as well for proper budget income of company towns and a wages level. Thus, the conducted analysis offers to differentiate the following variety of HHI for diversification process evaluation in different economic activities:

- HHI of dispatched goods concentration;

- HHI of investments concentration;

- HHI of personnel number concentration;

- HHI of tax liabilities concentration.

The system of indexes will allow studying the economic structure transformation in dynamic.

\subsubsection{Factors of industry diversification}

Industry diversification is the process initiated by investments structure changes. Russian company towns become the object of modernization that assumes the new diversification projects elaboration. All developed projects are systemized in Complex Plan of Company Town Modernization [11] that acts as the core instrument of strategic planning for diversification process of company towns. The general structure of investments and its distribution in diversification projects are the basic factors of economic transformation. The preparation of the Complex
Investment Plan of Company Town Modernization is an obligatory condition for attracting state investments in Russia. This process began with state program of company town diversification in 2010 and initially included 3 pilot company towns in Kemerovo region that received state investments on public-private partnership principles (Leninsk-Kuznetsky, Procopievsk, Tashtagol). Currently the official list of company towns includes 24 settlements from Kemerovo region: 19 towns and 5 urban villages, whereas the total number of the towns in the region is 20 .

Investments inflow should be considered as the result of activities of investment attractiveness development. Investment attractiveness here stands for the subjective estimation by investor the factors of investment potential and investment risks [12-13]. The factors of investment potential consist in production, infrastructure, customers, workforce, innovations, and institutions. Investment risks of a company town include economic, financial, social, ecological and criminal risks [14]. Investment attractiveness improvement in a company town will cause the investment growth whereas the diversification strategy development and fulfillment will gain the economy transformation with less concentration of core industry.

\subsection{Social results of diversification}

The mission of company town diversification reflects the basics of mission statement for all settlements and is figured out in social wellbeing improvement (living standards and longevity development). A diversification strategy serves to create the economic basis for social prosperity. We studied 24 Complex Plans of Company Town Modernization in Kemerovo region and have defined the basic socio-economic target of diversification - an unemployment rate that values specifically between $0,8-1,5 \%$ by 2020 .

In company towns the dependence between economic indexes and social ones is extremely high because a town-forming enterprise generates dominant part of workers. According to the Russian legislation a company town currently should have over $20 \%$ of workers engaged in core industry for the last 5 years [14]. This criterion was stated in 2014 and has become the first dynamic criterion of company towns differentiation.

\section{Methodology}

Considering the statistics data we suggest to estimate HHI indexes of dispatched goods concentration, investments concentration, and employment concentration in Berezovsky company town located in Kemerovo region. The database includes figures for the period of 2007-2014. It allows making conclusion on transformational changes in company town economy in dynamics.

Let $k_{i}$ be the value of the factor (investments, dispatched goods, and average number of personnel) in a particular type of economic activity including the core 
industry; $S$ - the total value of the factor (investments, dispatched goods, and an average number of personnel); $i$ - the particular type of economic activity in company town; and $n$ - the number of economic activities according to the official statistical approach. HHI is figured out in the following (1):

$$
H H I=\sum_{i=1}^{n}\left(\frac{k_{i}}{S} * 100\right)^{2}
$$

The index value is in the range of [10000/n; 10000]. This interval differs in accordance with the number of estimated issued that should be applied for the particular study. The company town diversification process of Berezovsky is discovered by concentration of investments in economic activities $\left(\mathrm{HHI}_{1}\right)$, dispatched goods in industry $\left(\mathrm{HHI}_{2}\right)$, and average number of personnel in different economic activities $\left(\mathrm{HHI}_{3}\right)$.

The relevance between economic and social transformation is suggested to assess on the basis of correlation analysis. Thus, it will assist to define the relevance and social effectiveness of the diversification.

\section{Results and Discussions}

Berezovsky had come into the official list of company towns in 2014. The economy structure of Berezovsky comprises the types of economic activities systematized in this research as shown in Table 1.

Table 1. The structure of HHI of investments concentration $\left(\mathrm{HHI}_{1}\right)$, dispatched goods concentration $\left(\mathrm{HHI}_{2}\right)$, and average personnel number concentration $\left(\mathrm{HHI}_{3}\right)$.

\begin{tabular}{|c|c|c|c|}
\hline Activities & $\mathrm{HHI}_{1}$ & $\mathrm{HHI}_{2}$ & $\mathrm{HHI}_{3}$ \\
\hline Fossil fuel extraction & $\mathrm{X}$ & $\mathrm{X}$ & $\mathrm{X}$ \\
\hline $\begin{array}{l}\text { Extraction of minerals except } \\
\text { fuel }\end{array}$ & $\mathrm{X}$ & $\mathrm{X}$ & $\mathrm{X}$ \\
\hline Manufacturing & $\mathrm{X}$ & & $\mathrm{X}$ \\
\hline Food & & $\mathrm{X}$ & \\
\hline Publishing & & $\mathrm{X}$ & \\
\hline Rubber and plastic & & $\mathrm{X}$ & \\
\hline Metallurgical products & & $\mathrm{X}$ & \\
\hline $\begin{array}{l}\text { Non-metallic mineral } \\
\text { products }\end{array}$ & & $\mathrm{X}$ & \\
\hline Machines and equipment & & $\bar{X}$ & \\
\hline Miscellaneous & & $\mathrm{X}$ & \\
\hline $\begin{array}{l}\text { Energy and water input- } \\
\text { output }\end{array}$ & $\mathrm{X}$ & $\mathrm{X}$ & $\mathrm{X}$ \\
\hline $\begin{array}{l}\text { Wholesale and retail trade, } \\
\text { repair of motor vehicles, } \\
\text { household goods and } \\
\text { personal items }\end{array}$ & $\mathrm{X}$ & $\mathrm{X}$ & $\mathrm{X}$ \\
\hline $\begin{array}{l}\text { The activity of hotels and } \\
\text { restaurants }\end{array}$ & $\mathrm{X}$ & & $\mathrm{X}$ \\
\hline $\begin{array}{l}\text { Transport and } \\
\text { communication }\end{array}$ & $\mathrm{X}$ & & $\mathrm{X}$ \\
\hline Finance & X & & $X$ \\
\hline Real estate & $\bar{X}$ & & $\bar{X}$ \\
\hline $\begin{array}{l}\text { Public administration and } \\
\text { security and social insurance }\end{array}$ & $\mathrm{X}$ & & $\mathrm{X}$ \\
\hline Education & $\mathrm{X}$ & & $\mathrm{X}$ \\
\hline Health and social services & $\mathrm{X}$ & & $\mathrm{X}$ \\
\hline
\end{tabular}

\begin{tabular}{|l|c|c|c|} 
Other services & $\mathrm{X}$ & & $\mathrm{X}$ \\
\hline \multirow{2}{*}{ HHI value range } & {$[769 ;$} & {$[1000 ;$} & {$[769 ;$} \\
& $10000]$ & $10000]$ & $10000]$ \\
\hline
\end{tabular}

The Complex Investment Plan of Berezovsky Company Town Modernization [11] defines the following diversification targets by 2020 :

1) Core industry dispatched goods share at the level of $49 \%$

2) New and existing non-core industries share: $30,5 \%$;

3) Small business share in production: $30,5 \%$;

4) Unemployment rate: $1,4 \%$;

5) Average wages growth: in 1,6 times.

The authors deem it advisable to complete the stated targets with the employment rate in core industry, own incomes in local budget, and an investments share in diversification projects that should be evaluated on the basis of the dynamic analysis of concentration indexes.

The core industry for Berezovsky is a fossil fuel extraction that gains $73 \%$ of the total dispatched goods in 2014 and over $80 \%$ in 2015 with less than $10 \%$ of investments into it. Over $27 \%$ of personnel are engaged in the core industry for the last 5 years that meets the basic legal criterion of company town differentiation in Russia.

Due to the statistic database restrictions the authors took the deliberate decision to calculate $\mathrm{HHI}_{1}$ and $\mathrm{HHI}_{3}$ on the bases of 13 types of economic activities according to the official statistic approach. The last causes HHI value range within $[10000 / 13 ; 10000]$. Otherwise $\mathrm{HHI}_{2}$ is evaluated according to 10 types of economic activities specifying the company town industry. $\mathrm{HHI}_{2}$ value range is $[10000 / 10 ; 10000]$ as shown in Table 1 . Thus, $\mathrm{HHI}_{1}$ and $\mathrm{HHI}_{3}$ could be compared being in the same conditions, whereas $\mathrm{HHI}_{2}$ is quite different. The results of the study are considered in dynamics and presented in Figure 2.

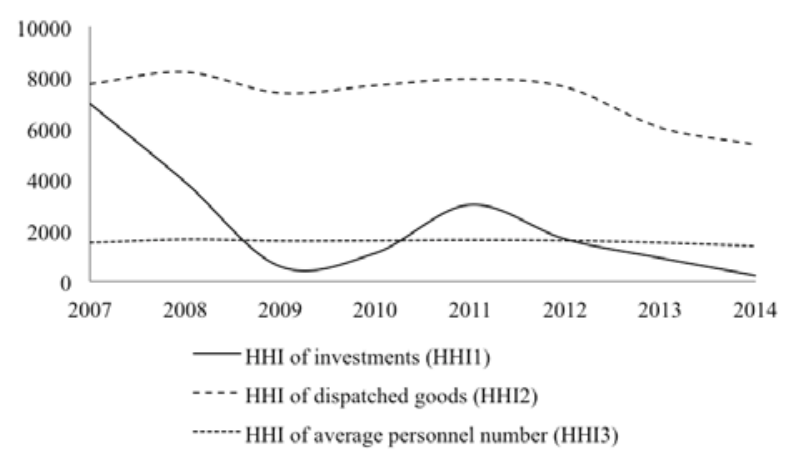

Fig. 2. HHI of investments, dispatched goods and an average personnel number in Berezovsky, Kemerovo region.

The research of the concentration level of investments, dispatched goods in industry, and average personnel number in Berezovsky in 2007-2014 has brought to the downfall dynamics in $\mathrm{HHI}_{1}, \mathrm{HHI}_{2}$, and $\mathrm{HHI}_{3}$. $\mathrm{HHI}_{1}$ shows the most significant reduction from 6995 to 251 in 2007 and 2014, respectively. The share of investments in the core industry for the considered period shows the steady 9-fold decline from $83 \%$ in 2007 to $9 \%$ in 2014 as shown in Figure 3. $\mathrm{HHI}_{2}$ reflects the fair decrease of concentration in dispatched goods 
from 7735 to 5377 in 2007 and 2014, respectively. The core industry share in dispatched goods in the same period fell down from $88 \%$ to $73 \%$. Personnel number concentration $\left(\mathrm{HHI}_{3}\right)$ for the considered period represents a slight downward tendency and reduces from 1510 to 1392 in 2007 and 2014, respectively. At the same time the core industry share has more than $30 \%$ in 2007 and $27 \%$ in 2014.
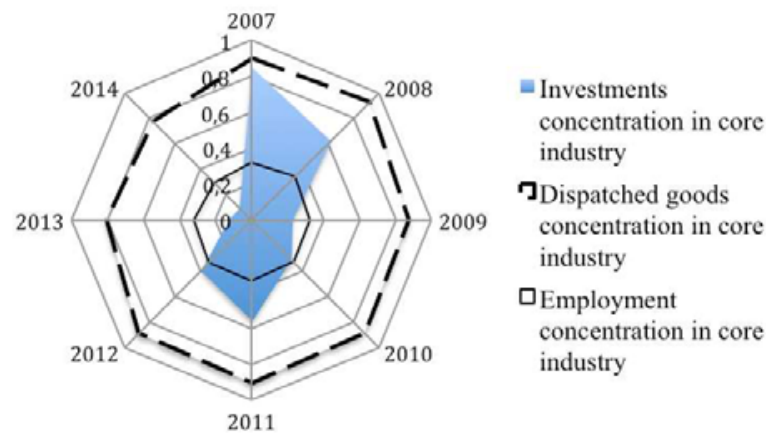

Fig. 3. The core industry transformation in Berezovsky, Kemerovo region.

The dynamics of investments concentration reflects the crisis of 2008 and funding the diversification projects in 2011-2015. Being the external factor, the crisis is not under consideration here. Investments in new projects should become the major factor of diversification effectiveness. Nevertheless, the rate of investments in diversification projects is an extremely low value that presented in Table 2.

Table 2. The share of investments in diversification projects from total investments in Berezovsky, Kemerovo region, \%.

\begin{tabular}{|c|c|c|c|c|}
\hline Activities & $\mathbf{2 0 1 1}$ & $\mathbf{2 0 1 2}$ & $\mathbf{2 0 1 3}$ & $\mathbf{2 0 1 4}$ \\
\hline $\begin{array}{c}\text { Fossil fuels } \\
\text { extraction }\end{array}$ & 0,07038 & 0,02885 & 0,00252 & 2,11554 \\
\hline Manufacturing & 0,00027 & 0,00075 & 0 & 0,13918 \\
\hline $\begin{array}{c}\text { Energy and } \\
\text { water input- } \\
\text { output }\end{array}$ & 0,00001 & 0,00526 & 0,00506 & 0,39117 \\
\hline $\begin{array}{c}\text { Wholesale and } \\
\text { retail trade }\end{array}$ & 0 & 0 & 0,0006 & 0,14651 \\
\hline $\begin{array}{c}\text { Other services } \\
\text { Total }\end{array}$ & 0,0005 & 0,00002 & 0,00003 & 0,00293 \\
\hline
\end{tabular}

The analysis of the investment rate of diversification projects shows the positive dynamics: from $0,07 \%$ in 2011 to $2,8 \%$ in 2014 . The basic share of investments in diversification projects was directed in fossil fuels that remained the core industry of the town. Taking all these into consideration we may conclude that the effectiveness of Berezovsky economy diversification is quite low.

Apart from the economical factors of diversification, the social ones are highly important. Being the mission of town development, social wellbeing is the final goal of the diversification process. The principal target of diversification stated in the Complex Investment Plan of
Berezovsky Company Town Modernization is an unemployment rate. The correlation analysis shows the low relations between an unemployment rate and concentration of investments, dispatched goods, and a personnel number considering 2007-2014. It is confirmed by the correlation coefficients: $r_{1}=-0,324$ between an unemployment rate and investments in a core industry, $r_{2}=0,014$ between an unemployment rate and dispatched goods of core industry, and $r_{3}=0,059$ between unemployment and an average personnel number. The moderate and weak correlation with even inverse dependence does not allow concluding on social effectiveness of the diversification process.

\section{Conclusion}

The conducted research defined the basic tendencies in economic activities concentration in 2007-2014. It was a downward dynamic that does not stand for the diversification process. Herfindahl-Hirschman index in dynamics allowed concluding the structural transformation of Berezovsky company town economy. Nevertheless, the factors of transformation are not completely clear because the investments in diversification projects have an extremely low value as well as there is not any considerable and reliable correlation between them.

\section{Acknowledgment}

The reported study was supported by RFBR, research project No. 16-36-00294 mol_a "The dynamic approach to effectiveness evaluation of diversification of a company town economy".

\section{References}

1. H. Green, The Company Town: The Industrial Edens and Satanic Mills That Shaped the American Economy (New York: Basic Books, 2010)

2. D.Y. Zemlyansky, S.V. Lamanov, Bul. of Mosc. Un., 4, 69-74 (2014).

3. S. Burder, Pullman: An Experiment in Industrial Order and Community Planning, 1880-1930 (Urban Life in America, 1967)

4. R.A. Miller, Antitr. Bull., 27, 593 (1982)

5. E. Nauberg, K. Basu, H. Chand, Apl. Econ. Let., 4, 10 (1997)

6. S. Calkins, Calif. Law Rev., 71, $402-429$ (1983)

7. S.A. Rhoades, 79 Fed. Res. Bull., 79, 188 (1993)

8. Y.O. Susilo, K.W. Axhausen, Transportation, 41(5), 995-1011 (2014)

9. Y.A. Zhemchuzhnicova, Mess. of Orenb. St. Un., 9, 118-121 (2008)

10. D. Carson., D. Carson, A. Henderson, North. Inst. Res. Br. Ser., 5, 1-14 (2014).

11. Complex Investment Plan of Berezovsky Company Town Modernization (2010)

12. I.S. Antonova, O.A. Negodina, D.D. Vavilov, Proceed. IBIMA, 2181-2187 (2015) 
13. I.S. Antonova, O.A. Negodina, K.S. Koptelova, L.Y. Spitsina, S.N. Popova, D.D. Vavilov, Adv. In Comp. Sc. (EMCS 2016), 904-907 (2016)

14. G.D. Antonov, O.P. Ivanova, I.S. Antonova, Economist, 6, 83-89 (2011) 